
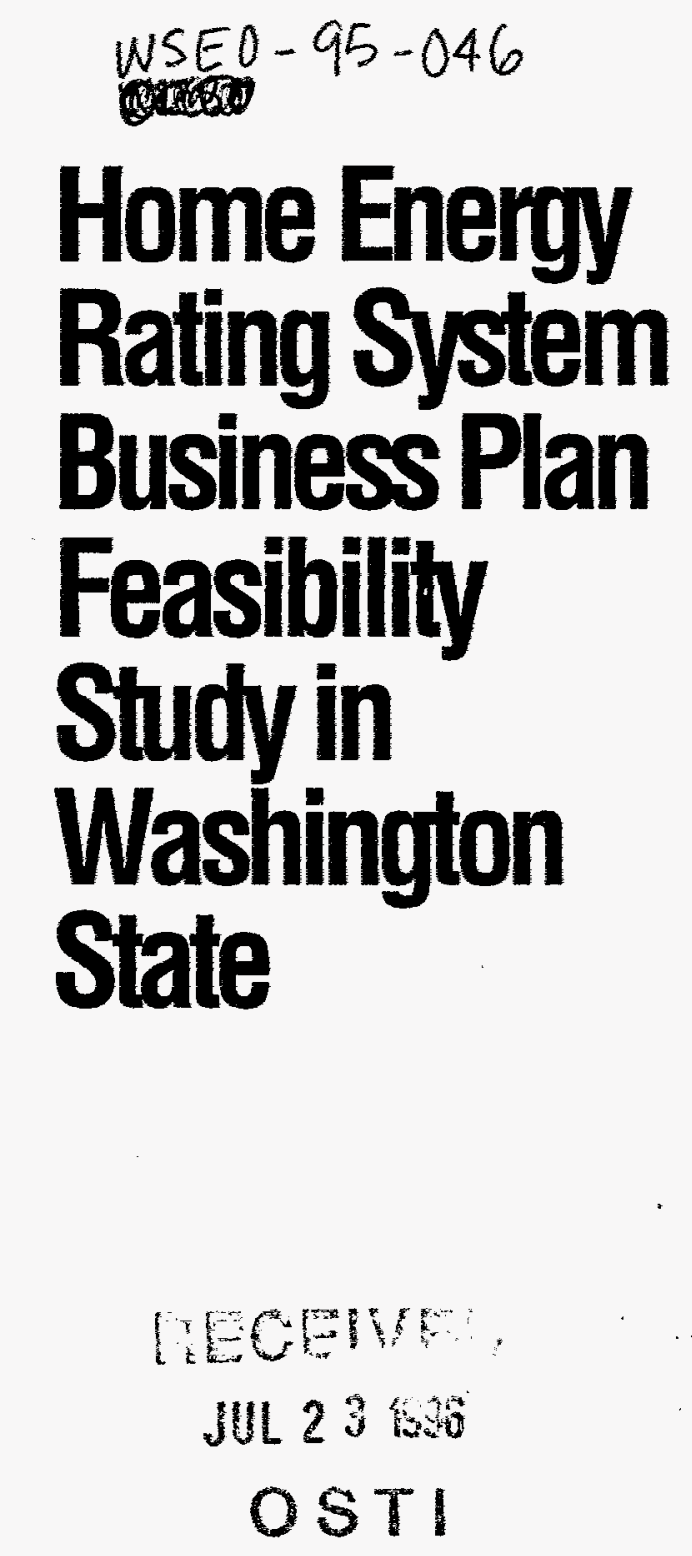

DISTABUTION OF THIS DOCUAENT IS UNLMPEO

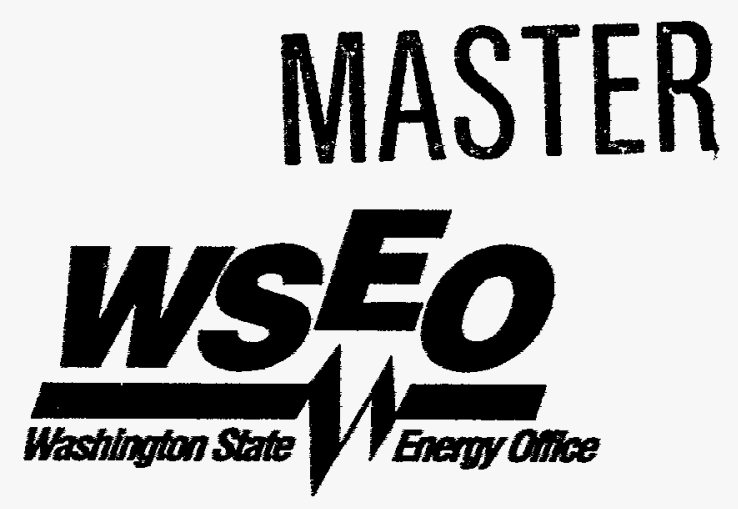




\section{Home Energy Rating System Business Plan Feasibility Study in Washington State}

Prepared by:

Tom Lineham, Project Manager, Javier Figueroa, Project Lead, Angela Burrell, Evaluation and Research, Elizabeth Klumpp, Policy Review

.Washington State Energy Office

This report can be made available in 925 Plum St. SE, Building \#4.

in another format for people with disabilities. Please call (360) 956-2068. Olympia, WA 98504-3165

TDD users call (360) 956-2218.

Note: The telephone area code will change January 15, 1995. After this date, use area code 360 .

Printed on recycled paper

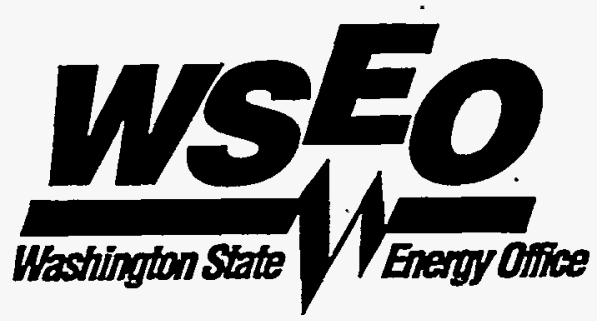


This document will be made available through the National Technical Information Service. 


\section{DISCLAIMER}

Portions of this document may be illegible in electronic image products. Images are produced from the best available original document. 
$\begin{array}{ll}\text { Executive Summary } & 1\end{array}$

Background $\quad \cdot 1$

Findings 1

Conclusions $\quad 2$

Introduction $\ldots \ldots$

$\begin{array}{ll}\text { Potential Consumers } & 3\end{array}$

Potential Market Niche $\quad 5$

$\begin{array}{ll}\text { Products and Services } & 7\end{array}$

Possible Options and Approaches

in Establishing the Venture $\quad 8$

Possible Financing Plan 9

Other Issues $\quad$ • 11

$\begin{array}{ll}\text { Rating Tools } & 11\end{array}$

Source Versus Site $\quad$. 11

Figure 1

Existing Financial Options Available to

Washington State Consumers Involving

Installation of Energy Efficient Measures $\quad 8$

Table A

Housing Units Constructed to MEC or Better

Table B

Washington Home Energy Rating System

Possible Budget Scenario

Attachment: Consumer Value of Energy Efficiency in the Housing Market Appendix A

Appendix B 

In the Fall of 1993, the Washington State Energy Office (WSEO) funded the Washington Home Energy Rating System (HERS) project to investigate the benefits of a Washington state HERS. WSEO established a HERS and EEM (Energy Efficient Mortgage) Advisory Group. Composed of mortgage lenders/brokers, realtors, builders, utility staff, remodelers, and other state agency representatives, the Advisory Group met for the first time on November 17, 1993. The Advisory Group established several subcommittees to identify issues and options. During its March 1994 meeting, the Advisory Group formed a consensus directing WSEO to develop a HERS business plan for consideration. The Advisory Group also established a business plan subcommittee to help draft the plan. Under the guidance of the business plan subcommittee, WSEO conducted research on how customers value energy efficiency in the housing market. This plan represents WSEO's effort to comply with the Advisory Group's request.

In its most basic form, a home energy rating system establishes an organizational approach to rating homes based on relative energy use efficiency of both new and existing housing. The rating is based upon, but not limited to, the thermal envelope, HVAC system, and water heating efficiency and is determined either on site through inspections, measurements and diagnostic procedures or through certified documentation. This concept presumes that if value for energy efficiency is better recognized by the market place it in turn may result in the access of certain financial options involving the property.

Unlike the Corporate Average Fuel Efficiency or the USDOE appliance standards there is no momentum to establish a mandate for a home energy rating system on the federal level. Given that such a mandate is unlikely, a voluntary home energy rating system must be self-financed. However, to counteract market place resistance leading lenders, seçondary market players and Congress have established new lending tools and policies which reinforce energy efficient mortgages and home energy rating systems.

There is no guarantee that the establishment of a HERS could pay for itself. Like any new business venture, the HERS organization would face uncertainty and risk. In the long run, market forces will determine a HERS' viability.

According to WSEO research, consumers are more likely to make cosmetic changes to their homes than install energy efficient measures. And further, a home rating itself is not sufficient to induce a home owner to install new energy efficient measures or to stimulate energy savings.

Since not enough consumers in the market place recognize energy efficiency improvements as adding value to property Washington state appraisers have not consistently assigned such improvements with value. It is difficult for appraisers to recognize energy efficient properties since few are labeled.

There is some reason to believe that state utilities may have a primary interest in supporting EEM and HERS programs. In Washington state several communities have successfully operated EEM pilots with the support of local utilities. 
This study identifies two possible sources of income to base the funding of a HERS: income derived from rating and labelling of homes and income derived from selling possible HERS products and services to utilities to complement their weatherization programs.

To overcome the market place barriers and to establish a successful Washington state HERS program the HERS would have to adopt a comprehensive education and marketing campaign.

There is value in educating consumers on the costs, savings, and comfort benefits associated with purchasing and owning energy efficient homes. One benefit is consumers are aware of their energy operating costs; another benefit is educated consumers may implement cost-effective energy saving measures. This information can be disseminated to consumers through education, marketing, or the media; this does not require a rating system infrastructure. To have a greater impact on consumers program promoters must link this information to comfort, convenience, lifestyle, and aesthetics. Utilities may implement such a marketing campaign as part of a customer service effort or to obtain energy savings. Public sector organizations may promote such programs to encourage cost effective energy conservation.

A rating system with standardized information may benefit lending institutions in their efforts to qualify buyers of energy efficient homes by increasing the debt-toincome ratio. Some institutions implement this practice with energy efficient mortgages.

A successful HERS program could complement utility weatherization programs: 1) HERS could provide additional marketing to an existing program;2) utilities may coordinate with contractors to educate homeowners about the costs and benefits of including energy efficiency upgrades during a remodel; 3) utilities may lower administrative program costs by cooperatively funding one or more central points of contact for weatherization programs; 4) a HERS program could benefit weatherization customers who gain ready access to information on financing programs and options.

At this time, the goal of operating a local or statewide HERS program should not be to obtain direct energy savings. The little data that exists for HERS programs in other states indicates they have had very low participation levels (ranging from $9 \%$ to less than $1 \%$ ); and those ratings resulted in few, if any, energy saving actions to date. ${ }^{1}$

The design of a specific HERS program would depend upon the type of organization that was promoting it. Lending institutions that are seeking to qualify buyers with an improved debt-to-income ratio may already focus their programs on new and existing energy efficient homes through the use of the energy efficient mortgage. Utilities seeking to encourage customers to weatherize their homes may focus on older existing homes.

Burrell, Angela, Consumer Value of Energy Efficiency in the Housing Market: Implications for a Home Energy Rating System in Washington, WSEO, February 1995. 
In the Fall of 1993, the Washington State Energy Office funded the Washington Home Energy Rating System project to investigate the benefits of a Washington state HERS. WSEO established a HERS and EEM Advisory Group. Composed of mortgage lenders/brokers, realtors, builders, utility staff, remodelers, and other state agency representatives, the Advisory Group met for the first time on November 17,1993 . The Advisory Group established several subcommittees to identify issues and options. During its March 1994 meeting, the Advisory Group formed a consensus directing WSEO to develop a HERS business plan for consideration. The Advisory Group also established a business plan subcommittee to help draft the plan. Under the guidance of the business plan subcommittee, WSEO con- . ducted research on how customers value energy efficiency in the housing market. This plan represents WSEO's effort to comply with the Advisory Group's request.

Why is a HERS Business Plan necessary? Strictly speaking this plan is more of a feasibility plan than a business plan since it is designed to help determine the feasibility of a new business venture: a statewide home energy rating system. To make this determination decision makers or possible investors require strategic information about the proposed enterprise. Ideally, the plan should anticipate the significant questions parties may want to know. Among other things, this document should establish decision points for action.

This plan discusses the following issues:

- the potential consumer base: the possible beneficiaries

a the potential market niche

- product and services

- possible options and approaches in establishing the venture

- possible financing plan including capital formation

- other significant issues

What is a HERS? Who may benefit? In its most basic form, a home energy rating system establishes an organizational approach to rating homes based on relative energy use efficiency of both new and existing housing. The rating is based upon, but not limited to, the thermal envelope, HVAC system, and water heating efficiency and is determined either on site through inspections, measurements and diagnostic procedures or through certified documentation. This concept presumes that if value for energy efficiency is better recognized by the market place it in turn may result in the access of certain financial options involving the property.

WSEO found four major groups of potential beneficiaries for a state HERS/EEMs program:

- Owners/Buyers of new homes or homes already built to high energy efficiency standards/codes

- Owners/Buyers of existing homes without energy efficiency improvements

- Utilities

- Industry allies 
In the State of Washington, over 300,000 homes (including all fuels) have been built to energy efficiency standards equal to or exceeding the International Council of Building Official (CABO) Model Energy Code (MEC) standard (1992). The National HERS Council has recognized CABO's MEC's standards as the basis for high energy ratings. HUD and FannieMae, among other secondary market sources, have specifically developed guidelines recognizing these properties in Washington as qualifying for the energy efficient mortgage. In addition, these properties have already received various levels of documentation identifying their efficiency measures. See Table A for potential homes in Washington state eligible for a high rating.

\section{Table A}

Housing units constructed to MEC or better

Super Good Cents Homes: 1986-1992 2

153,434

MAP homes (includes SGC MFH): $1986-1994^{3}$

64,500

Washington State Energy Code: $1991-1994^{4}$

96,200

'Northwest Energy Code: 1984-1995

21,675

Total

335,809

Total housing units in Washington State through $1990^{5} \quad 2,000,000$

In addition the Department of Community, Trade and Economic Development identified over $40,000^{6}$ homes which have received some level of energy efficient improvements through low income weatherization programs administrated through county organizations. Utilities have also provided weatherization programs for customers throughout Washington state, but the data is not available at this writing.

This means that more than $10 \%$ of the current Washington housing properties could be primary beneficiaries of the energy efficient mortgage based on energy efficiency if appropriately identified through ratings, labels or listings. In addition, these properties represent the easiest to document since all have been built to existing codes or program standards. Unfortunately, few lenders currently promote or offer energy efficient mortgages in the state.

A second potential beneficiary of HERS and EEMs may be the property owners of the other $90 \%$ of Washington housing stock not built to high energy codes who may have interest in energy conservation measure retrofit programs. Some utilities currently have waiting lists for their weatherization programs. But not all home owners see enough value in participating in the utility's program. HERS,

Supplied by Bonneville Power Administration staff, January 1995

3 Davey, Don, Memo 12/29/94 (MAP figures oniy, see footnote 2 for SGC MFH)

4 Spreadsheet supplied by Alan Mountjoy-Yenning, WSEC program, WSEO, December 1994

5 Bureau of the Census, 1990 Census of Population and Housing

6 Washington Department of Community, Trade and Economic Development, An Assessment of Low-Income Needs in Washington State (draft), November 1993, p153 
which features additional financing tools, might bring new consumers into weatherization programs. However, unlike homeowners who own properties built to MEC code level, this customer group would have to undertake a series of decisions to realize improvements before receiving high ratings (such as a major remodel event). In most HERS states, where energy codes don't exist, this group represents the primary consumer group for participating in a rating system.

A third potential group to benefit from a HERS/EEMs program, it could be argued, would be state utilities which invested rate payer dollars into programs that resulted in high energy efficiency codes and standards. These codes capture important conservation resources and reduce the need for new, more expensive generation. Utilities may obtain added customer value by providing a rating which identifies homes as energy efficient. In addition, utilities consider such programs as weatherization, a valuable customer service and their customers may benefit from the educational component of a HERS.

In surveying Washington utilities, WSEO found many utilities believe a successful HERS could complement their weatherization programs by providing additional marketing; by possibly lowering administrative costs through economies of scale; and by providing additional value to their consumers (better access to possible financing tools and information).

Finally a fourth, rather broad group of program beneficiaries could be the industry allies such as: lenders, realtors, remodelers and subcontractors. All stand to benefit from increased sales, commissions, or market opportunities.

As a basic concept HERS encompasses a variety of market niches such as resale, remodel, weatherization housing markets as well as new construction and manufactured homes. Each market niche connects different types of HERS products. For instance, for new residential construction, a consumer would most likely have an interest in using the energy efficient mortgage or using FannieMae's Community Homebuyer program. A consumer interested in achieving energy efficiency benefits (and hence a higher rating) during a remodel effort may access information on FannieMae/HUD's Title 1 Property Improvement Loan Program. (See Product and Services section for more examples). In many ways a successful HERS is a marketer of information.

Where do possible revenue sources exist in these markets to fund a HERS? Two possible sources seem plausible: revenues derived from performing ratings and from providing services to utility weatherization programs.

300,000 homes in Washington state could conceivably already qualify for a high energy rating under a HERS if based on the CABO MEC. Purchasers of these homes should automatically receive an EEM under existing programs. However a number of barriers exist in the market. These barriers include: lack of interest in and therefore lack of knowledge of energy conservation benefits in general by consumers; lack of interest in and therefore lack of knowledge of potential lending tools available to their customers for documented energy efficiency by lenders; and, because not enough consumers in the market place recognize energy efficiency improvements as adding value to property, Washington state appraisers have not consistently assigned such improvements with value. It is difficult 
for appraisers to recognize energy efficient properties anyway since few are labeled. On the other hand, appraisers in HUD pilot states have begun to show added value. To overcome the barriers above and to establish a successful Washington state HERS program the HERS must adopt a comprehensive education and marketing campaign.

In its research report, WSEO found consumers are far more interested in financing cosmetic changes to their property. ${ }^{7}$ In the same report, WSEO reviewed regional homeowner surveys which indicated the average citizen rates energy conservation as very desirable. But to act on an opinion is a different matter. To gain the highest resale value for a home, the market place recognizes many other home improvements before most energy efficient improvements. The market place provides a high payback for kitchen remodeling, adding a full bath, bath remodeling, adding a master suite, adding a sun room, providing a fire place, installing skylights or new siding. The highest ranked energy improvement involves windows, one of the least cost effective measures in terms of energy efficiency. 8

Perhaps a more lucrative revenue source for a successful HERS venture may be to serve as marketing enhancement for current utility weatherization programs. Utilities are reconsidering conservation program design in light of recent industry restructuring. Many Washington state utilities are currently evaluating their weatherization programs in light of the Bonneville Power Administration's . announced desire to shift responsibility for conservation programs to its customer utilities.

There is some reason to believe that state utilities may have a primary interest in supporting EEM and HERS programs. In Washington state several communities have successfully operated EEM pilots with the support of local utilities: the Tri-cities area has implemented FannieMae's $3 / 2$ program using utility incentive payments as part of the down payment; a lender and Clark PUD have provided support in applying the debt-to-income ratio increase for loan qualifications involving new electrically heated homes built under the Washington State Energy Code (WSEC) ${ }^{9}$; PacifiCorp and other utilities have proposed a pilot financing program for MAP homes which calls for, among other things, a lower interest rate for personal property loans than currently available.

WSEO's research has found limited supportive evidence from other states involved in HUD's HERS pilots. ${ }^{10}$ Most states have yet to realize their potential as envisioned by their sponsors. However, few have existed for more than two years and have not had time to establish themselves in the market. Washington state could learn from other states in terms of start up time lines. At present the states have had varying degrees of success in providing energy audits but have yet to exhibit that a home energy rating itself is sufficient to induce a home owner

8 - Remodel Means Resale, The Olympian, March 26, 1994, pE1.

9 In recent reports from Norwest Mortgage, Inc. and First Interstate Bank these two banks have generated over 1600 EEMs at a home sale value of over \$106 million from July 1993 to present.

HUD pilots include: Vermont, Virginia, Colorado, Alaska, Arkansas and California. 


\section{Products and Services}

to install new energy efficient measures. However, in one pilot state, Alaska, realtors offer to pay for the cost of a rating as part of a home sale.

The Washington market niche for a possible HERS is greatly impacted by the overall national mortgage and housing industries. The more HERS concepts are incorporated into national market forces, standards and guidelines, the more likely a HERS program in Washington state will realize success.

The most fundamental product of a HERS is a rating of home energy efficiency based upon installed energy efficiency measures to some agreed upon standard acceptable to the lending industry. Home ratings come in a number of different packages: stars, percentage rank, numeric accounting, UA (a value which measures heat transfer)or Uo derivatives and so on. To gain a rating, a consumer must request an audit whereupon a HERS auditor inspects the home. In the case of Washington, many homes built to energy efficient codes and standards, already have means to document efficiency levels. Based on proper documentation and for a fee, HERS can provide the appropriate rating much more easily for these homes than by conducting an audit.

A second product line could derive from utility weatherization services. Besides providing ratings to the utility, a HERS could also supply other services to the utility and its customers. This could include: auditing and inspection services, administrative support, lending information, matching utility and lending programs and so on. Indeed, assuming it is cost effective for the utility, a HERS could provide a complete weatherization package for a utility. The more utility programs offered through a centralized HERS, the more the HERS could realize economies of scale.

Most of the HERS products are linked to national lending guidelines developed . either through legislation such as the National Energy Policy ACT (1992) or through secondary market players such as FannieMae, HUD, VA etc. Each year market players announce new lending terms based on energy efficiency and over the past decade the possibilities have broadened for the consumer. Basic tools now include the energy efficient mortgage which embodies the debt-to-income ratio increase for loan qualification. Other tools include special advantages offered for home improvement loans for energy efficiency measures (see Figure 1). 


\section{Figure 1}

\section{Existing Financial Options Available to Washington State Consumers Involving Installation of Energy Efficient Measures}

- Energy Efficient Mortgage Program.

a HUD 203K Program. This program assists in the financing of purchase/rehabilitation or refinance/rehab transactions for one to four family residential properties. Provides one long term loan for purchase and rehabilitation. Includes a wide range of home repairs and remodeling.

- FannieMae:

Central Cities for enhanced Fannie Neighbors with the Community Home Buyer's Program.

Community Home Improvement Mortgage Loan.

Community Subsidized Second Mortgages.

Community Home Buyer's Program with the 3/2 Option.

HUD/Fannie Pilot Title 1 Property Improvement Loan Program.

- Farmers Home Administration: 502 Loan Program.

- Veteran Administration program for purchases of rehabilitation of homes. Special considerations for installing energy efficient measures.

Freddie Mac programs.

In addition, a HERS is ideally situated to coordinate local, statewide and regional efforts to gain additional advantages for the consumer. For example, PacifiCorp has recently provided an outline on how, if utilities coordinated, they could affect better mortgage terms for manufactured home buyers if they strategically leveraged their MAP DSM payments in the Pacific Northwest. ${ }^{11}$ By leveraging the utility residential DSM programs, HERS could help develop new product lines. While the above capabilities are not strictly HERS products and services, they do illustrate how additional products and services could come on line.

Possible Options and Approaches in Establishing the Venture
Various organizational structures currently exist which could provide the basis for a HERS business venture.

- Private non profit corporation.

- Private corporation. 
Public non profit corporation.

- A utility consortia (Such as the Utility Code Group) .

- Part of state govemment (such as the Housing Finance Corporation).

Ideally, the organization should cover the entire state of Washington though a possible HERS pilot could be established to serve one geographic area for instance. Energy offices in neighboring states have shown interest in forming HERS. Some advantages could be achieved if the HERS becomes a regional organization (or at least coordinates with efforts elsewhere in the region).

Capital formation is a major issue which will be discussed in more detail in the next section. Unlike the HUD pilot states, Washington state has no identifiable state funds at this time to assist in starting such a program. Federal agencies such as EPA, DOE, and HUD have all offered minimal funding for the states, but with anticipated federal downsizing, Washington state should not count on much from this direction

In keeping with a Business Plan format, we have outlined below a possible budget scenario for HERS. This serves as a possible starting point for discussion.

\section{Financial Projection and Program Budget}

\section{Summary of Expenses}

Table B represents the projected fully loaded cost for operating a statewide . HERS organization for five years. The budget includes four full-time equivalent (FTE) staff as well as a healthy marketing line item. If the organization decides on a less ambitious direction such as a pilot (or fewer components of a HERS such as a financing hotline) in a limited service territory, the project budget of course, should be adjusted accordingly. Care should be taken to determine appropriate fixed costs for other options and impact on possible unit costs.

\section{Project Phase-in}

Key to the establishment of this HERS scenario is that interested parties can sign agreements for the delivery of HERS products and services: membership, ratings, marketing etc. Due to the different decision making processes of potential partners, this scenario expects a gradual phase in of activities. This is not reflected in Table $B$ but should be addressed by the HERS. The board will have to establish appropriate priorities for the business' viability at various levels of effort. 
Table B

- Washington Home Energy Rating System Possible Budget Scenario

Expenses

Year 1 Year 2 Year 3 Year 4 Year 5.

Salaries

224

230

238

245

253

Rent

20

21

21

22

22

Equipment

20

2

2

2

5

Professional Services

18

22

22

22

25

Travel

Training

Rating Tool

8

8

10

10

30

Advertising/Marketing

250

Other

Total Expenses

$\begin{array}{rr}4 & 4 \\ 584 & -552\end{array}$

5

4

10

4

4

10

10

5

5

5

$200 \quad 200 \quad 150$

4

4

4

$506 \quad 514$

478

Revenues

Membership Fees

82

Utility Bridge Loans

484

80

60

130

Utility Service Agree.

242

292

100

204

552

556

100

Total Revenues

584

\section{Summary of Revenue}

This scenario anticipates three primary sources of on-going revenue: membership fees, rating fees and utility agreements. Membership fees will derive from organizations and associations, private and pubic, which find an interest in participating in HERS program activities. These could include: lending institutions, mortgage insurance companies, product manufacturers, realtors, builders and trade allies, research institutes, and governmental entities.

A basic service which HERS will provide to the public includes an eniergy efficiency rating for homeowners (or their representatives). Considerable Washington state residential stock has already benefited from weatherization programs or from improved energy codes. These homes could be documented with little effort and receive ratings at a minimal expense. These fees could be paid for directly by the benefiting homeowner or as a product purchased on behalf of the homeowner by a utility or another entity.

While the above fees represent important elements to the HERS budget, the primary sources of revenue for the HERS rest with products for purchase by a utility through contract or utility service agreements (see below). Under this scenario utilities can enter into agreements with HERS to purchase from a menu of possible weatherization, informational and/or labeling products. 
To start up, HERS will require seed capital for the venture. The HERS can capitalize its program through early contracts with utilities either in form of bridge loans or service agreements (see below). If utilities opt to participate in a bridge loan arrangement, HERS must develop an appropriate payback schedule which could include delivery of services. HERS could endeavor to convert bridge loans into utility service agreements. These contracts would bring "up front" capital into HERS for initial operating purposes.

\section{Utility Service Agreements}

The viability of this scenario rests on the establishment of long term utility service agreements. The HERS organization and utilities would enter into negotiations to determine costs for supplying a variety of potential products. Ideally these services could reduce utilities' costs for current weatherization services (marketing, auditing, maintaining a bidder's list) and/or enhance the current products the utilities supply to their customers (ratings, financing options).

Other organizations may enter into similar agreements with HERS for specific services (such as referrals 800 information number).

Other issues

Rating Tools

Source Versus Site

The HERS Advisory Group discussed several additional issues beyond the scope of this plan that require consideration.

The "Tools" subcommittee investigated a number of approaches for designing tools from very simple designs to very complex. In addition, the subcommittee examined tools in operation for other states. At this writing, numerous examples exist for a Washington state HERS to evaluate.

A major issue for the HERS to address involves the definition of energy efficiency for the purposes of establishing a program baseline. What should be included? Some argued that efficiency should be measured from its source to the home taking into account the inefficiencies involved in generation and transmission. Others felt the measurements should only include those measures found or installed on site. The National HERS Council recommended HERS system should use a site based measurement. Reinforcing this approach, some lenders on the HERS Advisory Group felt the program should avoid variable costs such as fuel costs and focus ratings on the installed hardware which remain with the structure for its life. This issue needs resolution. 


\section{Attachment}




\section{Consumer Value of Energy Efficiency in the Housing Market}

Implications for a Home Energy Rating System in Washington

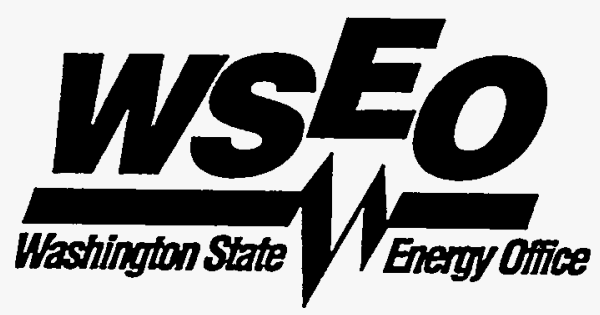




\section{Consumer Value of Energy Efficiency in the Housing Market}

Implications for a Home Energy Rating System in Washington

March 1995

WSEO \#95-080

This report can be made available in in another format for people with disabilities. Please call (360) 956-2068. TDD users call (360) 956-2218.

Note: The telephone area code will change January 15, 1995. After this date, use area code 360 .

Printed on recycled paper

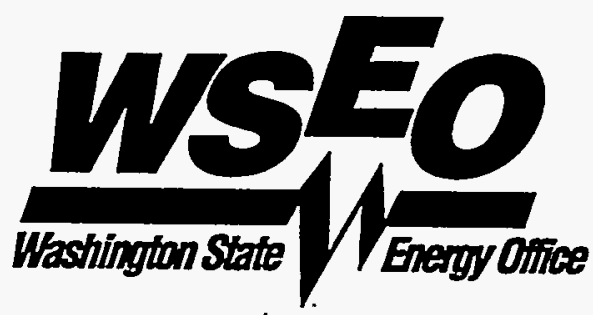


Since 1993, the Washington State Energy Office (WSEO) has been working with the shelter industry, the finance industry, and utilities to identify parties who may have a stake in the formation of a Home Energy Rating System (HERS) program. Interested parties have joined together to form the HERS Advisory Committee, sponsored and coordinated by the WSEO Residential Unit.

While the concept of the role a HERS in Washington is evolving, a basic framework has been identified to facilitate discussion and evaluate the potential value of a HERS in Washington State. At this time, a HERS in Washington is viewed as a tool in the form of an energy efficiency rating system that could be voluntarily applied to existing homes to enable homeowners, homebuyers and homesellers to make a reasonable consideration of a home energy cost in the retrofit, purchase, or sale of a home.

The HERS Advisory Committee formed a Business Planning Committee to define the HERS product, evaluate and assess the consumer market, and develop the business plan. Among the host of consumer issues evoked by the Business Planning Committee, the list boils down to one main concept: If we build it, will they come? Or, in other words, will a Home Energy Rating System motivate consumers to install more home energy conservation measures, buy, and/or sell more energy efficient housing stock than they do currently? This is a broad consumer question dealing with a set of issues addressed in this report:

- How important is energy efficiency and conservation to consumers?

- What are the characteristics of the decision-making environment associated with home buying/repair/improvement?

- What value do consumers place on energy efficiency compared to other attributes? Are consumer choices motivated by energy efficiency?

- What is the likelihood that an energy rating will lead to consumer action that ultimately results in the improvement of the energy efficiency of an existing home?

To characterize consumer value relative to home energy efficiency, consumers were defined by their marketplace capacities: homebuyer, homeowner and homeseller. Several studies conducted with Pacific Northwest consumers over the past fifteen were reviewed in compiling this report. The studies provide useful background in considering the likely reception and impact of a HERS in the Washington State housing market.

\section{Consumers}

Energy efficiency is important but not a priority. Studies showed that while homeowners felt conservation was important, it is less important than more salient issues such as nuclear energy production or waste, or other national problems. When considering whether or not they would pay for energy efficiency improvements on their home, many survey respondents said they would prefer to make behavioral changes than pay for improvements.

Existing energy information is underutilized. Purchasers of existing homes already have the option of reviewing past utility bills or previous audit information, but evidence shows that while some are already using this information to 
capitalize energy efficiency features into a home's market value, the majority of home buyers do not request to see past energy bills. A Washington State Energy Office survey of homebuyers found that 80 percent of the respondents felt that home energy efficiency was important but 60 percent did not ask the seller to present past fuel bills, and 86 percent did not inquire about an audit. At the same time, research shows that utilities, utility bills and inserts are among the highest ranked sources of energy information trusted by consumers.

\section{Homebuyers: Competing Aspects of the Purchase Decision}

Energy efficiency, a rational factor in the purchase decision, is secondary to other rational (practical) factors. Homebuyers simultaneously consider a number of features using objective and empirical information to logically weigh the alternatives. At the same time, intuitive assessments are taking place. Energy effi- . ciency does not stand out among the reasons why people choose one particular home over another. In fact, it is a nearly a minor consideration, in view of the comparably more salient elements, such as location, floorplan, comfort, and lifestyle.

Energy efficiency translated as a comfort factor, may have some impact on the purchase decision- but not uniquely decisive impact. Intuition and frustration often accompany the decisionmaking process. A Seattle survey respondent said: "..I think it is somewhat emotional, and you have about 15 items bouncing around in your head, all of a sudden you say, 'this is it." [1] Researchers also found that when a task becomes more complex (involves more altematives), or when the environment imposes pressure (poses deadlines, etc.), there is a tendency to use cognitively easier decisionmaking strategies rather than more demanding ones. As the features of a home increase or vary from home to home, the importance of the energy label decreases. A fundamental characteristic of energy labels and information is that it stimulates comparison across alternatives when altematives are more similar, but once the decision maker employs highly selective strategies, this comparative feature will likely lose impact.

\section{Homeowners and Homesellers Focus on Urgency, Comfort and Cosmetics} Energy efficiency is a byproduct of home improvement or repair. Homéowners' purchase of conservation measures is linked with home improvements or repairs. Installation of energy conservation measures often hinges upon the performance of home improvement or repair tasks which are often triggered by urgent needs or opportunities. The likelihood of when or if homeowners will make improvements or repairs is uncertain. Audits sometime lead to energy efficiency improvements which, most likely, will be paid for with cash.

If energy efficiency is more likely linked to repair/remodel issues, perhaps sale of energy efficiency is better-off in the home improvement market than in the home purchase market. From the perspective of a HERS, this may suggest that association with home loans or mortgages for retrofits, is not the optimal situation. If consumers who choose to install conservation measures are more likely to do so when they build or remodel and less likely to borrow money to do so, it may be more logical to conduct efforts that address the marketing side of home remodeling and improvement rather than the finance side. 
Homesellers appeal to buyers' interest in cosmetic features; and not in energy efficiency features. Homeseller interest in energy efficiency is fairly nonexistent and even in the remodel area the tasks that rank the highest in terms of cost recovery are: kitchen remodel, bathroom remodel, master suite, sun room, family room with fireplace or skylights, new siding, etc.

\section{HERS Programs in other States: Inconclusive Impacts}

No conclusive data showing impacts of ratings due to the installation of energy efficient measures. Few of the organizations contacted track the post improvement rating or the installation of energy efficient measures and those that did, did not have significant data.

-Benefits of rating: raising awareness of energy efficiency. Staff and directors characterized the benefits of the programs as vehicles for raising consciousness about home energy conservation in communities. Most also did not expect to have a significant impact in the market until energy prices rise high enough to motivate consumers to change their behavior.

\section{Conclusions}

- Consumers are likely to hold the attitude that energy efficiency and conservation are important but do not consider them a priority compared to more immediate concerns or to cost issues.

- Homebuyers use a complex decision-making process in purchasing a home. Among the several competing priorities that cloud the process, those that emerge often override energy efficiency considerations, such as location, floorplan, comfort, and lifestyle. Energy labels demonstrating efficiency have been proven to be effective when product features are more similar but as product features increase and vary among each other, energy efficiency labels are less effective.

- Homeowners are more likely to install energy efficient measures as a byproduct of a remodel or repair or in response to immediate needs or opportunities-and more likely to pay with cash.

- Homesellers are more likely to be interested in cosmetic improvements that improve convenience or appeal to aesthetic needs of homebuyers.

While overall, energy efficiency is a low priority for home dwellers, the conclusions suggest that consumers, especially homeowners may be interested in learning more about the energy efficiency of their home. Since homeowners are more likely to purchase energy conservation during a remodel or repair event, this market is a potential audience for energy efficiency products. Access to this group could be gained in any number of ways and based on the limited success HERS have found in other states, other options should be competitively considered.

Among those elements that home dwellers embraced, the most likely that can be associated with energy efficiency are comfort and lifestyle. Marketing efforts attempting to sell energy efficiency should emphasize these elements in order to reach consumers and change behavior. 
A HERS approach may be somewhat premature due to the general lack of consumer concem about energy efficiency and the fact that fuel prices in Washington remain low. In some cases (existing audits and utility, bills), a similar type of information generated through ratings is already available to consumers but goes unused. It may be useful to consider alternatives that reach the emotional, aesthetic, and cultural needs of consumers. 
"To date, there has been very little evaluation of any of the HERS programs conducted in the U.S. and even less of the impact of the marketing strategies employed." (page 12)

"A majority of programs have conducted no market research of either a primary or secondary nature to help in designing the deployment of the program, or to determine the impact of a program once it has been launched. For those programs that have, the most commonly used primary approach is focus groups...to try to establish the potential level of interest/use of such programs. The principal form of secondary research that is conducted is sharing information with other program operators...."(page 19) [3]

Since 1993, the Washington State Energy Office (WSEO) has been working with the shelter industry, the finance industry, and utilities to identify parties who may have a stake in'the formation of a Home Energy Rating System (HERS) program. Interested parties have joined together to form the HERS Advisory Committee, sponsored and coordinated by the WSEO Residential Unit.

The concept of the role a HERS can play and the manner in which a HERS program should be developed and implemented in Washington State is evolving, but a very basic framework has been identified to facilitate discussion and evaluate the potential value of a HERS in Washington State. At this time, a HERS in Washington is viewed as a tool in the form of an energy efficiency rating system that could be yoluntarily applied to existing homes to enable homeowners, homebuyers and homesellers to make a reasonable consideration of a home energy cost in the retrofit, purchase, or sale of a home. A HERS program would be implemented by an independent, private or non-profit organization, ratings would be performed by trained, independent individuals, and the cost of the rating would likely be carried by the consumer.

The HERS Advisory Committee formed a Business Planning Committee to define the HERS product, evaluate and assess the consumer market, and develop the business plan. The Business Planning Committee requested assistance from the WSEO Program Research, Planning and Evaluation Unit in evaluating and assessing the consumer market in relation to a HERS: That is the purpose of this report.

Information contained in this report consists of secondary sources (existing literature) and primary sources including information from multiple listing services in Washington State and from HERS program directors throughout the United States.

Among the host of consumer issues evoked by the Business Planning Committee, the list boils down to one main concept: If we build it, will they come? Or, in other words, will a Home Energy Rating System motivate consumers to install more home energy conservation measures, buy, and/or sell more energy efficient housing stock than they do currently? This is a broad consumer question dealing with a set of issues addressed in this report:

How important is energy efficiency and conservation to consumers? 


\section{Energy Efficiency in the Housing Marketplace}

What are the characteristics of the decision-making environment associated with home buying/repair/improvement?

- What value do consumers place on energy efficiency compared to other attributes? Are consumer choices motivated by energy efficiency?

- What is the likelihood that an energy rating will lead to consumer action that uitimately results in the improvement of the energy efficiency of an existing home?

The main reason why consumer behavior and consumer interest is so important in building a HERS program is because the rating tool created will only be useful if it means something in the marketplace-if it can be applied in comparing the value or attributes one home with another. Creating an additional challenge is the fact that the rating would be voluntary and most likely paid for by the homeowner. If consumers, especially existing homeowners, do not see value in it, it will not be used.

The findings presented in this report address the issues raised above and raise others for further consideration by the HERS Advisory and the Business Planning Committees as they consider the feasibility of a HERS program in Washington State.

The Business Planning Committee has also expressed interest in sponsoring primary research in the form of a random telephone survey of Washington residents to obtain direct and immediate consumer perspectives on energy efficiency. Based upon existing financial limitations, the Committee decided to forego this option unless additional funding is located.

In characterizing the value consumers place on home energy efficiency, consumers must be viewed in their marketplace capacities as: homebuyer, homeowner and homeseller. Energy efficiency is a somewhat intangible, hidden product often entangled among the features of a home. Variability imposed by differing consumption levels and housing structures may cause an energy conservation measure to be effective in one home and useless in another. Market value of energy efficiency as a product cannot easily be separated out in financial terms.

Over the past fifteen years, several applicable studies have been conducted with consumers in the Pacific Northwest to gauge priorities and views relative to energy efficiency and housing. These studies assess probable and self-reported actions and views of homebuyers, homeowners, and homesellers. They provide a useful background for the consideration of the likely reception and impact of a HERS in the housing market.

\section{Consumers: Energy Efficiency is Important but Not a Priority}

Thoughts versus actions. How homeowners and homebuyers feel about energy efficiency is one thing; what they do about it is another. The majority of residents and homeowners living the Pacific Northwest feel energy conservation and efficiency is important but, when energy is compared to other issues, it is less important. A survey of Washington residents conducted in 1988 asked respondents to describe statewide problems or concerns. Unemployment, taxes, education, and 
the environment were major concems. The only energy related issues mentioned were about nuclear production and nuclear waste. [7]

A 1983 survey of residents in the Pacific Northwest addressing homeowner attitudes toward energy conservation, found that respondents "consider energy conservation as significant to their lives to a greater extent than homeowners in other areas of the United States"- 80 percent of survey respondents said they feel energy conservation is a " serious issue". However, when considering whether or not they would pay for energy efficiency improvements on their home, over half said they would prefer to make behavioral changes than pay for improvements. [8]

Existing energy information is underutilized. A telling example of how consumers would make use of the information provided by a home energy rating is a review of how they have used similar existing information. Purchasers of existing homes already have the option of reviewing past utility bills or previous audit information. However, evidence shows that while some are already using this information to capitalize energy efficiency features into a home's market value, the majority of home buyers do not request to see past energy bills. A Washington State Energy Office survey of homebuyers found that 80 percent of the respondents felt that home energy efficiency was important but 60 percent did not ask the seller to present past fuel bills, and 86 percent did not inquire about an audit. At the same time, research shows that utilities, utility bills and inserts are among the highest ranked sources of energy information trusted by consumers. $[2,5,8]$

The relative apathy toward energy information is demonstrated by the experience of a rating program in Visalia, California. The rating program used a slew of promotional efforts (flyers, mailings, phone calls, newspaper articles, and personal contact) in reaching 530 owners and renters; only 13 percent agreed to do a rating. Non-participants were surveyed to determine the reasons why they chose not to participate. Among the reasons respondents gave for their lack of interest were: 1) already audited, 2) belief that motive for rating was to sell them something, 3) satisfied with their energy costs, 4) belief that no energy improvements are needed. [2]

While Washington State consumers have more favorable attitudes toward energy conservation in general, prior research has shown that favorable attitudes toward energy conservation or energy conservation programs do not necessarily translate into conservation behavior or actual energy savings. [2]

\section{Homebuyers: Competing Aspects of the Purchase Decision}

Energy efficiency, a rational factor in the purchase decision, is secondary to other rational (practical) factors. The decision-making process involved in the purchase of a home is a complicated one; probably the most complicated purchase a typical person or family faces in a lifetime. Justifiably so, the process consists of both rational and emotional dimensions. [1]

Within the rational dimension, homebuyers simultaneously consider a number of features using objective and empirical information to effectively weigh the alternatives. The consideration of items follows a logical, rational order while, at the same time, intuitive assessments are taking place: Among the variety of rational, 
objective features considered, the following elements are common priorities for a majority of people: location, floorplan, storage, comfort (including even heating), and ease of cleaning. Beyond this, most people have a laundry list of features, some of which, are less tangible than others.

The emotional side of homebuying consists of considerations such as "fit" with personal or family lifestyle and aesthetic "feeling". Homebuyers refer to the "rightness" of a home beyond its ability to meet their needs for the basic, rational features. [1]

Energy efficiency translated as a comfort factor, may have some impact on the purchase decision- but not uniquely decisive impact. Energy efficiency does not stand out among the reasons why people choose one particular home over another. In fact, it is a nearly a minor consideration, in view of the comparably more salient elements, such as location, floorplan, and lifestyle. Respondents to one survey were asked to consider to trade-off other amenities (dishwasher, dining room, etc.) for energy efficiency; the majority of respondents considered the amenities over energy efficient components. Homebuyers associate energy efficiency with the rational, practical item-the utility bill- and not with other aesthetic or physical characteristics. Based on the relatively low cost of residential fuel in Washington, it is likely that energy efficiency will remain a low priorityunless there is a meaningful increase in fuel prices.

Further compounding the process and contributing to the obscurity of energy efficiency in the home purchase decision, is the complexity and stress of the homebuying process itself. Intuition and frustration often accompany the decisionmaking process. A Seattle survey respondent said: “..I think it is somewhat emotional, and you have about 15 items bouncing around in your head, all of a sudden you say, "this is it."' [1]

A study of consumer response to energy efficiency labeling of appliances assessed the conditions under which people are likely to take into consideration energy efficiency. In noting the wide range of decision strategies employed by consumers, the researchers found that when a task becomes more complex (involves more alternatives), or when the environment imposes pressure (poses deadlines, etc.), there is a tendency to use cognitively easier strategies rather than more demanding ones. "As information search becomes more selective across decision alternatives, the impact of symbolic energy labels [or energy information] will decrease." Or, in other words, as the features of a home increase or vary from home to home, the importance of the energy label decreases. More choices reduce interest in energy information. [12]

A fundamental characteristic of energy labels and information is that it stimulates comparison across altematives when alternatives are more similar, but once the decision maker employs highly selective strategies, this comparative feature will likely lose impact. This corroborates the decision making process used in home selection, identified earlier. 
Homeowners, Homesellers: Energy Efficiency as a Byproduct of Other Actions

For homeowners, the role of energy efficiency is somewhat more straightforward since it is associated with the specific purchase of conservation measures as opposed to being absorbed into the cost of a home.

Energy efficiency is a byproduct of home improvement or repair. Homeowners' purchase of conservation measures is linked with home improvements or repairs. A survey of 800 Seattle-area homeowners showed that 78 percent had made home improvements or repairs in the past. The reasons for the improvements or repairs ranked from highest to lowest: necessity (53\%), attractiveness (32\%), comfort, livability (20\%), increased home value (9\%). Twenty-nine percent of the respondents installed energy conservation measures. The reasons for installation ranked from highest to lowest: utility bill savings (54\%), save energy (50\%), necessity (18\%), comfort, livability (17\%). Respondents did not associate resale value with energy conservation measures.

So, for homeowners, the installation of energy conservation measures often hinges upon the performance of home improvement or repair tasks which are often triggered by urgent home repairs, home improvement or remodeling tasks. General home improvement measures are more likely to occur in the first year of ownership, when the first child is expected, and/or when the children have left home- with a fraction associated with conservation. [8]

Most home improvement is due to immediate need or opportunity. The likelihood of when or if homeowners will make improvements or repairs is uncertain. When asked to identify plans for future home improvements, only one-third mentioned that they had something in mind; not necessarily energy-related. Some homeowners have projects in mind but the majority of home improvement is due to immediate needs (leaking roof, high energy bills) or opportunities (special offers, etc.).

Audits sometime lead to energy efficiency improvements...which, most likely, will be paid for with cash. Findings conflict over whether or not having an energy audit significantly increases the number of installed measures, or not. One study reports that 1 out of 3 audits were influential when combined with financing or rebates. Another study shows that in some cases nearly twice as many specific measures were installed in homes with audits compared to those without audits (nearly 60 percent of the audits were enabled through grants or rebates).

Research also shows that homeowners overwhelmingly prefer to pay as they go when making repairs, improvements, or installing conservation measures. One study indicated that nearly 70 percent of the respondents paid cash for past conservation measures and 73 percent indicated that they would borrow money for these efforts "only as a last resort."

Given consumer disposition toward audits, they are less likely to pay to have a rating assigned, more likely to pay for measures if they have paid for a rating, more likely to pay in cash and less likely to take out a loan to cover their expenses. From the perspective of a HERS, this may suggest that association with home loans or mortgages for retrofits, is not the optimal situation. If consumers who choose to install conservation measures are more likely to do so when they 
build or remodel and less likely to borrow money to do so, it.may be more logical to conduct efforts that address the marketing side of home remodeling and improvement rather than the finance side.

Homesellers appeal to buyers' interest in cosmetic features (intuitive); and not in energy efficiency features (rational). Homeseller interest in energy efficiency is fairly non-existent in Washington. Homeowners as potential homesellers have not demonstrated an interest in building resale through the installation of energy conservation measures. Improvements that have been identified to achieve maximum payback are generally cosmetic. Among the remodel tasks that rank the highest in terms of cost recovery are: kitchen remodel, bathroom remodel, master suite, sun room, family room with fireplace or skylights, new siding, new windows, new doors. Unfortunately, some of these may even increase . energy consumption or result in heat loss.

A recent review of energy features recorded in Washington state multiple listings showed that 2 to 3 percent of the homes listed demonstrated the existence of components related to home energy efficiency. Multiple listing service databases rarely include fields for specific energy features. Energy-related information is in comment fields, if it's there at all. As one multiple listing service director put it"Tell us what to look for and how to understand it and that might encourage more entry of energy information." Multiple listings may not represent the whole realty market but they are a good indicator of what kind of information the shelter industry and consumers rely on in the marketplace. See Appendix A for more information.

\section{Other States' Experiences with HERS Programs}

Several HERS programs exist in the United States. Some are part of a national HERS effort, while others are operating independently. Varying degrees of research and information exist on the various HERS programs. Some HERS programs started out with market research surveys or focus groups while others started forward without market information. Some states have conducted limited review while others have documented the history and progress of their programs. Few states, if any, have evaluated the process or impact of their HERS programs although some studies have been conducted that compare the structure of various programs. See Appendix B for a summary of research conducted on programs nationwide.

Most programs associate ratings with loan procurement. The majority of ratings conducted are "as is"- prior to energy efficient improvements. Comparatively few "post-improvement" inspections or ratings are conducted even though these are required to obtain the loan adjustment for energy efficient measures.

Rating organizations are often non-profit groups funded in a variety of ways; initial funding is sometime obtained through grants, government subsidies, oil overcharge funds, etc.; ongoing funding is achieved through organization membership fees, government funding, utility funding or a combination of sources. 
We contacted staff at several energy rated home programs throughout the country in order to leam about their experience and impacts with ratings in their state.

The chart below shows the penetration rate of a few rating programs.

No conclusive data showing impacts of ratings due to the installation of energy efficient measures. Few of the organizations contacted track the post improvement rating or the installation of energy efficient measures and those that did, did not have significant data. A study conducted in 1986 noted that the question of whether ratings are resulting in energy savings remained unanswered although, based on calculated models of potential savings and practical knowledge about energy efficient housing, "it does seem reasonably clear that HERS programs are contributing to more energy efficient housing and to corresponding energy savings." This same report also noted that "energy efficient housing provides no guarantee that projected savings will occur". [2] It seems that the question about impact, that existed in 1986, exists today. Before we can know the impacts, more reliable tracking and monitoring practices must occur.

Benefits of rating: raising awareness of energy efficiency. Noting the relatively low number of ratings that have been conducted in comparison to the target populations and the lack of information about the installation of energy efficient measures, we asked HERS program staff and directors to identify the benefits or success indicators of their programs. Most said that they viewed their role as raising consciousness about home energy conservation in communities. Most also

\begin{tabular}{|c|c|c|c|c|c|}
\hline State & $\begin{array}{l}\text { Program } \\
\text { Start Date }\end{array}$ & $\begin{array}{l}\text { Target } \\
\text { Market }\end{array}$ & $\begin{array}{c}\text { Market } \\
\text { Size }\end{array}$ & $\begin{array}{c}\text { Number * } \\
\text { of Ratings* }\end{array}$ & $\begin{array}{r}\text { Penetrat } \\
\text { Rate }\end{array}$ \\
\hline California & 1993 & $\begin{array}{l}\text { single-and } \\
\text { multi-family }\end{array}$ & $11,000,000$ & $\begin{array}{r}\text { approx. } \\
16,000\end{array}$ & $.0 \%$ \\
\hline Arkansas & 1987 & $\begin{array}{l}\text { single family new } \\
\text { and existing }\end{array}$ & 8,000 & 743 & $9 \%$ \\
\hline Alaska & 1989 & $\begin{array}{l}\text { single-and } \\
\text { multi-family }\end{array}$ & N/A & 10,088 & N/A \\
\hline Colorado, state & & $\begin{array}{l}\text { program in } \\
\text { development }\end{array}$ & & & \\
\hline Vermont & 1987 & N/A & N/A & 2,000 & N/A \\
\hline $\begin{array}{l}\text { Colorado, } \\
\text { Fort Collins } \\
\text { (city program) }\end{array}$ & 1988 & $\begin{array}{l}\text { new and existing, } \\
\text { single-and } \\
\text { multi-family }\end{array}$ & 35,000 & 650 & $2 \%$ \\
\hline
\end{tabular}

* None of the organizations contacted tracked post improvement ratings conducted since the beginning of operation. Most lumped pre-and post-improvement ratings at one point in their tracking process and had no way of separatingout the two numbers. 
did not expect to have a significant impact in the market, or rate a substantial amount of homes until energy prices rise high enough to motivate consumers to change their behavior.

There was a difference of opinion over whether a rating should be connected to the sale of a home or not. Those that opposed the idea of ratings linked to the homebuying process felt that home purchasing was an already too complicated event to incorporate the rating; they felt that energy related improvements were more likely associated with home remodel and repair. Those that felt ratings should be linked to the purchase felt that home loans were the most effective because they were a more tangible vehicle for a rating.

- Consumers are likely to hold the attitude that energy efficiency and conservation are important but do not consider them a priority compared to more immediate concerns or to cost issues.

- Homebuyers use a complex decision-making process in purchasing a home. Among the several competing priorities that cloud the process, those that emerge often override energy efficiency considerations, such as location, floorplan, comfort, and lifestyle. Energy labels demonstrating efficiency have been proven to be effective when product features are more similar but as product features increase and vary among each other, energy efficiency lábels are less effective.

- Homeowners are more likely to install energy efficient measures as a byproduct of a remodel or repair or in response to immediate needs or opportunities-and more likely to pay with cash.

- Homesellers are more likely to be interested in cosmetic improvements that improve convenience or appeal to aesthetic needs of homebuyers.

While overall, energy efficiency is a low priority for homedwellers, the conclu- . sions suggest that consumers, especially homeowners may be interested in learning more about the energy efficiency of their home. Since homeowners are more likely to purchase energy conservation during a remodel or repair event, this market is a potential audience for energy efficiency products. Access to this group could be gained in any number of ways and based on the limited success HERS' have found in other states, other options should be competitively considered.

A HERS approach is somewhat premature due to the general lack of consumer concern about energy efficiency and the fact that fuel prices in Washington remain low. In some cases (existing audits and utility bills), a similar type of information generated through ratings is already available to consumers but goes unused. It may be useful to consider alternatives that reach the emotional, aesthetic, and cultural needs of consumers.

Among those elements that home dwellers embraced, the most likely that can be associated with energy efficiency are comfort and lifestyle. Marketing efforts attempting to sell energy efficiency should emphasize these elements in order to reach consumers and change behavior.

An example of an alternative approach to changing behavior: The increased media and commercial attention to home improvement through existing national 
education and entertainment mechanisms, including television and media, indicates that the time may be ripe for a specially developed and presented public education effort at the local level. The rise of television shows such as Home Improvement, This Old House, Martha Stewart Living, Bob Villa, and the influx of · magazines including American Homestyles and the new Woman's Day Home Improvement magazines indicates that home improvement has become popular. Partnerships and efforts could be conducted in these commercial markets to increase public awareness of energy conservation.

The Harvard Alcohol Project is an example of a national effort that succeeded in mobilizing public opinion through a change in social norms promoted and modeled through mass communication. The Harvard School of Public Health launched a campaign to promote the "designated driver" campaign. They joined forces with the leading television networks and received funding from supporting foundations and corporations. Writers for major television sitcoms agreed to include references to the use of designated drivers into scripts of top-rated shows such as "The Cosby Show", "Cheers", and "L.A. Law". "The advantage of this approach is that short messages, embedded within dialogue, are casually presented by characters who serve as role models within a dramatic context, thereby facilitating social learning." (page 83) [15]

In addition to entertainment programming, their strategy has included news coverage, advertising, and grass roots community-based efforts to reinforce the impact of national media. Their efforts were widely endorsed by national opinion leaders, activist groups, public organizations and professionals. Program administrators met with producers and writers from all leading primetime television shows to encourage them to incorporate a variety of drunk driving prevention messages into scripts, encompassing prevention, deterrence and treatment. The point here is that while not always directly pushing the designated driver concept, the program was seeking to raise awareness about the problem of drunk driving so that when the designated driver message was heard, its benefits and reasons were well understood. Efforts extended over a four year period while the designated driver campaign was transformed into a national movement covering. a broad range of individuals and markets.

Survey data collected for the designated driver campaign has shown greater public support for laws and penalties associated with drunk driving, greater public acceptance of "anti-drinking" media, increased personal and social responsibility for drunk driving selves and friends, increased number of "designated drivers" and support for the concept.

This is one example of how the promotion of concept through a particular set of strategies has made a lasting impression because, through role models, leaders and friends, it has convinced individuals, social groups, and families that what they do is important. 


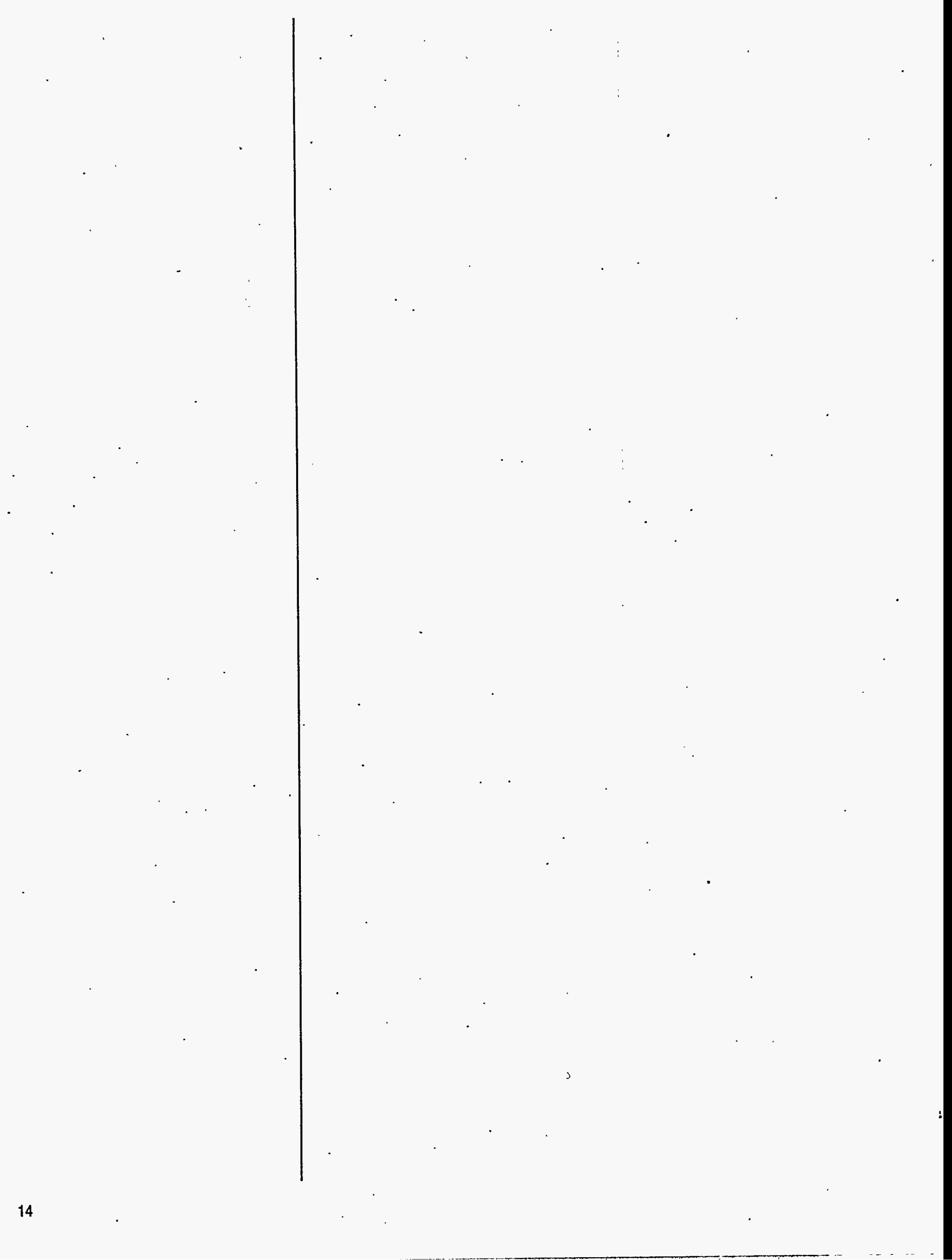


1. Bardsley \& Haslacher, Inc., Northwest New Home Buyers Discuss The Home Purchase Decision, August 1984.

2. Hendrickson, Paul, Review of Existing Residential Energy Efficiency Certification and Rating Programs, Battelle, PNL, November, 1986, Battelle PNL 6080 .

3. Infinite Energy, What Everybody Needs to Know about Marketing Home Energy Rating Systems, Denver, Colorado, December 1993.

4. Multiple Listing Service of Thurston County, Personal Communication, August 1994.

5. Patton, Anne Malean; Parker, Jerome F., Residential Energy Evaluation Program, Washington State Energy Office, March 1984, WAOENG-8409.

6. Puget Sound Multiple Listing, Association, Inc., Personal Communication, August 1994.

7. Rudeen, Shelley Kirk; Schueler, Vince, Public Views on Energy: A Review of the Literature, 1992, WSEO 92-076.

8. Sextent Consultants and O'Neill \& Company, Investigation of Factors Affecting Conservation Investment Decisions by Owner-Occupied, Single-Family Homes, Research Review; final and telephone interviews, June 1986.

9. Spokane County Multiple Listing Service, Personal Communication, August 1994.

10. Talmey Research \& Strategy, Inc., Colorado Office of Energy Conservation Home Energy Survey, Boulder, Colorado, May 1988.

11. The Results Center, Bonneville Power Administration, Super Good Cents, Profile \#7, IRT Environment, Inc., 1992.

12. Verplanken, Bas; Weenig, Mieneke W. H., Graphical Energy Labels and Consumers' Decisions About Home Appliances: A Process Tracing Approach, Journal of Economic Psychology, 14, 1993, 739-752.

13. Voories, Rebecca, Making 'HERS' a Household Word, Home Energy, September/October 1991

14. Yakima Association of Realtors, Personal Communication, August 1994.

15. Winsten, Jay A., Lessons from the Designated Driver Campaign, November 1992. 
Energy Efficiency Components Recorded in Multiple Listings
To gain some understanding of the prominence of energy efficiency in the housing market, short of contacting consumers directly, multiple listing service (MLS) databases were searched for mentions of energy efficient measures or utility packages. To obtain listings in a variety of climates, locations, and populations listings were reviewed in the following four areas served by four MLS services: 1) North Pierce, King, and Snohomish counties, 2) Spokane County, 3) Thurston County, and 4) Yakima County.

Most telling is the fact that, among the tens of data points included in a multiple listing for a single home, no field is designated for energy efficient measures or any related topic. The only piece of energy related information specified was fuel type. A conversation with the director of one MLS service resulted in a request for guidance in collecting energy related information meaningful to the energy and building industries and at the same time, useful to Realtors, lenders and consumers. A weatherization field previously existed in the MLS database; however, it was removed due to lack of information collected and supplied by the Realtors.

Searches were conducted with keywords in remark fields. Keywords used varied from region to region, based upon the kind of information most likely to be recorded. Each MLS organization was consulted in order to determine specific terminology the individual group used to represent energy efficiency.

Only 2 to 3 percent of the single family residential homes listed, noted energy efficient measures queried in the searches. Listings that noted insulation made reference to areas such as garages, attics, living areas, etc. Mentions of utility weatherization packages were most often associated with existing, older housing stock. Storm windows (double and triple paned), solar water heaters, heatpumps, weatherization, and related features were seldom noted.

In the colder, more arid region of Spokane County, there was a higher number of insulation mentions compared to other features, than in Puget Sound and Thurston County where utility packages received-more notations, compared to insulation. 


\begin{tabular}{|c|c|c|c|c|}
\hline \multicolumn{5}{|c|}{ Single Family Residential Homes Listed With Energy Efficient Components } \\
\hline $\begin{array}{l}\text { Multiple Listing Service } \\
\text { Area }\end{array}$ & $\begin{array}{l}\text { Number of Single Fam- } \\
\text { ily Residential Homes } \\
\text { Listed at Time of Search }\end{array}$ & $\begin{array}{l}\text { Number of Listings with } \\
\text { Energy Efficient } \\
\text { Measures Noted }\end{array}$ & Percentage & $\begin{array}{l}\text { Keywords Used in Data- } \\
\text { base Search (number of } \\
\text { notations in parentheses) }\end{array}$ \\
\hline $\begin{array}{l}\text { Puget Sound Region: } \\
\text { King County, Sno- } \\
\text { homish County, North } \\
\text { Pierce County } \\
\end{array}$ & 12,601 & 219 & $2 \%$ & $\begin{array}{l}\text { insulation (69) } \\
\text { energy package (149) } \\
\text { Puget Power package (1) }\end{array}$ \\
\hline Spokane County & 3,000 & 69 & $2 \%$ & $\begin{array}{l}\text { insulation (51) } \\
\text { Washington Water } \\
\text { Power Package (18) }\end{array}$ \\
\hline Thurston County & 1,097 & 35 & $3 \%$ & $\begin{array}{l}\text { insulation (6) } \\
\text { Puget Power package } \\
\text { (11) } \\
\text { energy efficient (18) }\end{array}$ \\
\hline Yakima County & not available & not available & not available & \\
\hline
\end{tabular}




\section{Appendix B \\ Summary of Research Findings Relating to Home Energy Conservation Programs} Survey of Residents on Energy Conservation Programs

Review of Existing Residential Energy Efficiency Certification and Rating Programs
Colorado Office of Energy Conservation In May of 1988, the Colorado Office of Energy Conservation (OEC) conducted a survey of 402 Colorado residents to determine what energy conservation programs the $\mathrm{OEC}$ should fund, attitudes about energy conservation, and to gauge acceptance of a Home Energy Rating System (HERS) for newly constructed homes. The findings showed the main motivation in home energy efficiency was cost. Only 16 percent considered saving energy resources important. Ninety-five percent of the respondents indicated that, all other things being equal, an efficient home is worth more money than an inefficient one. Of the features impacting home energy efficiency, respondents most frequently mentioned insulation; storm windows and furnaces were secondary mentions.

While younger people (18-44 years) were generally more aware of energy efficiency, older people (45-65 years) were more cognizant of the importance of thermostat setting. A higher percentage of younger people than older people associated day time use of home with greater energy usage.

Although the OEC's findings showed there was a high degree of interest in some of the programs presented in the survey, the evaluator concluded that the concern about energy efficiency and conservation was not enough to ensure the success of any of the programs. It was recommended that OEC should also appeal to economic interests. The OEC agreed any of the programs tested could help residents improve the energy efficiency of their homes, "but for widespread acceptance, it needs to attract people on the basis of their monetary self interest."

Battelle, PNL In the chapter on "Attitudes Toward HERS," Battelle wrote about the 1983 survey of recent homebuyers in King County. Of the 196 persons surveyed, 83 percent said they would have been very interested in knowing the energy efficiency rating of prospective homes they considered purchasing, 96 percent said a high rating would be important to their home selection process, 56 percent said were willing to pay up to $\$ 25$ for a rating on a desired home, and 57 percent said the possibility of obtaining more mortgage money through a high rating would have been influential in their home selection process.

Prior research also indicated favorable attitudes toward energy conservation programs do not necessarily result in energy conserving behavior or actual energy savings. 


\begin{tabular}{|c|c|c|c|}
\hline \multicolumn{4}{|c|}{ Pre-Launch Market Research Efforts Reviewed } \\
\hline Organization & Type & Target & Purpose \\
\hline $\begin{array}{l}\text { Bonneville Power } \\
\text { Administration }\end{array}$ & $\begin{array}{l}\text { Focus Groups, } \\
\text { Telephone Interviews }\end{array}$ & \begin{tabular}{|l|} 
Homebuyers \\
Builders \\
Realtors \\
\end{tabular} & $\begin{array}{l}\text { To establish awareness of } \\
\text { energy efficiency and the } \\
\text { program. }\end{array}$ \\
\hline $\begin{array}{l}\text { Califomia Home Energy } \\
\text { Rating System and Califormia } \\
\text { Energy Commission }\end{array}$ & Focus Groups & $\begin{array}{l}\text { Homebuyers } \\
\text { Builders } \\
\text { Realtors } \\
\text { Lenders } \\
\end{array}$ & $\begin{array}{l}\text { To determine the market and } \\
\text { interest for ratings. }\end{array}$ \\
\hline $\begin{array}{l}\text { Fort Collins Light and Power, } \\
\text { Colorado }\end{array}$ & Focus Groups & $\begin{array}{l}\text { Homebuyers (of existing } \\
\text { homes) } \\
\text { Homesellers (of existing } \\
\text { homes) Realtors }\end{array}$ & $\begin{array}{l}\text { To.obtain first-hand } \\
\text { information regarding how } \\
\text { they look at energy in this } \\
\text { process, how they would } \\
\text { respond to a rating system, } \\
\text { and how they responded to } \\
\text { specific promotion approaches } \\
\text { initially contemplated. }\end{array}$ \\
\hline $\begin{array}{l}\text { Colorado Office of Energy } \\
\text { Conservation }\end{array}$ & Phone Interviews & Residents & $\begin{array}{l}\text { Gauge public acceptance of a } \\
\text { HERS for new homes. }\end{array}$ \\
\hline
\end{tabular}

Survey of Residents on New Homes and Energy Efficiency
Boinneville Power Administration The Super Good Cents Program (SGC), which addresses shell improvements on new construction, conducted evaluations in $1987,1988,1989$, and 1992. Out of all electrically heated single and multifamily homes (including manufactured homes) constructed from 1986-1991, 25 percent were SGC certified.

The 1989 evaluation revealed 70 percent of the consumers felt energy efficiency was "very important" when considering a new home. A majority of consumers were also willing to spend an additional $\$ 4,000$ for energy efficient features in a new home. On the other hand, 46 percent of the builders in 1987 and 39 percent of the builders in 1988 considered energy efficiency to be "very important" and felt consumers would only be willing to spend an additional $\$ 1,000$ to $\$ 1,500$ on energy efficient features. BPA counts the following among its program successes:

- increased regional awareness of energy efficiency

- utility participation in the program

- creation or sustention of jobs

- development of support for the Northwest Energy Code

- increased regional capability to offer energy efficient new construction

Of the drawbacks, it includes:

- high operation costs in terms of labor, advertising, incentives

- labor and training for builders was not pervasive; many builders built only one home under the program

- higher penetration rates appear to require greater program investments 
Infinite Energy Infinite Energy, owned by Rebecca Voories, a leading national consultant in the home energy rating field, conducted a study of program pre-and post-launch market research efforts. The findings were reported in the report, What Everybody Needs to Know about Marketing Home Energy Rating Systems, December 1993. Research revealed most pre-launch market research has indicated potential users or consumers do not see a great need for the type of information generated through a rating, are not willing to pay much for it, and do not want to deal with financing energy improvements at the point of purchase. Consumers and professionals agree an intensive awareness and education effort would have to accompany a program in order for it to succeed.

However, response to the few satisfaction surveys that have been administered to users after their participation in the program shows a high degree of satisfaction with services received.

SGC Market Research; Prospective Homebuyers
Bonneville Power Administration Of some interest to the Washington State HERS Advisory Committee is the BPA SGC market research since it, in part, tepresents input from citizens of the Pacific Northwest including Washington State. Beginning in 1985, BPA conducted baseline or pre-launch research to establish baseline information about energy efficiency awareness and, later, post-launch research to assess changes in awareness and program awareness.

\section{Pre-Launch Research Findings}

Knowledge of Energy Efficiency. Solar features were considered the mark of an efficient house. Respondents noted more insulation, fewer windows, and better resale were among the features of an energy efficient house but had no reasoning of what the additional cost of an efficient home should be and generally overestimated the amount.

House Selection Priorities. BPA's program and market address new homes and new homebuyers who, based on previous living experience, started with a mental set of priorities about their needs. The priorities in looking for a home were: location, floorplan, storage, comfort (including even heat distribution), and ease of cleaning.

Extent of Willingness to Pay for Efficiency. Most of those surveyed indicated they would not pay more than 5 percent over the cost for additional energy saving features, that were proven. When asked if they would consider trading off other amenities (dishwasher, dining room, etc.) for energy efficiency, the amenities were preferred.

Attitudes Toward the Program Shortly After Launching: Implementation and Promotion. Of the few aware of the rating system, most associated it with a poor builder. Utilities were seen as a credible source of information of home energy efficiency information. Respondents wanted examples of how much they would have to invest to achieve efficiency and how long it would take to recover their investment. Saving money on utility bills was seen as the primary benefit of the program. Nearly all of those surveyed indicated they had some degree of interest in purchasing a home meeting the program standards. Regarding promotion and implementation of the program, the findings showed respondents did not consider Realtors as knowledgeable or credible regarding technical information 
about homes. None of the housing professionals received high ratings; however, builders were considered the most knowledgeable while lenders were considered the least knowledgeable. Respondents leaned toward promotional approaches that showed feature by feature improvements.

\section{Post-Launch Research Findings}

BPA's Post-Launch market research has consisted of telephone surveys of homebuyers and builders in 1986. Findings showed over half of the respondents would likely buy a SGC home while 45 percent preferred to buy resale housing where SGC would not apply. Eighty percent of the respondents associated insulation and storm windows with energy efficiency. Neighborhood and floorplan were again identified as the two highest values in selecting a home.

In 1987, a process and impact evaluation was conducted of the BPA program. Awareness targets were exceeded by eight percent. However, the sale of SGC Homes was less than originally targeted: 3.6 percent compared to a 10 percent target. A survey of prospective homebuyers revealed awareness of energy efficiency was only slightly higher than demonstrated in the baseline survey and homebuyers preferred an average incentive of $\$ 4,400$ to purchase a SGC House.

Overall, the combined findings demonstrated:

- Consumers have some knowledge of energy efficiency but do not agree on what makes a home efficient or how to compare different approaches.

- Consumers do not account for efficiency when buying, selling, or upgrading a house; consumers think rating information would be of interest but would not pay much or go out of their way for it.

- Consumers see strong benefits to an energy efficient home but are not sure the investment will pay for itself.

- Consumers would prefer some additional incentives to entice them but even this may not change their decisions significantly.

- Consumers respond to a wide range of information sources; and the housing industry and utilities are seen as good, thought not always accurate sources of information about energy issues. 